\title{
Teeming boisterous life
}

\section{Sensuous Seas: Tales of a Marine Biologist by Eugene $\mathrm{H}$. Kaplan}

Princeton University Press: 2006.288 pp.

$\$ 24.95, \notin 15.95$

\section{Jon Copley}

"What good men most biologists are, the tenors of the scientific world - temperamental, moody, lecherous, loud-laughing, and healthy," wrote John Steinbeck in The Log from the Sea of Cortez (Viking, 1951). "The true biologist deals with life, with teeming boisterous life, and learns something from it, learns that the first rule of life is living."

Steinbeck wrote those words on an expedition with his marine-biologist friend Ed Ricketts, but the description also seems to fit Eugene Kaplan, the author of Sensuous Seas. Kaplan's book is a compilation of entertaining anecdotes from a career that includes building fish farms in Africa, teaching science in Israel and establishing the Hofstra University Marine Laboratory in Jamaica. The book celebrates the joy of knowledge for its own sake, but also demonstrates some of the interactions between marine biology, everyday lives and even history.

Take the Mediterranean rock snail Hexaplex trunculus, which provided the purple dye used by royalty in the classical world. Exploiting the commercial opportunities of this snail's secretions made Phoenicia, now Lebanon, a major trading power. The same snail may also have been the 'hillazon' animal described in the Torah and the Talmud as the source of the dye used in Jewish prayer shawls. Kaplan also suggests that the fish used to feed the five thousand in the Bible would have been tilapia (pictured), whose hardiness holds promise for tackling famine through aquaculture today.

Kaplan has been teaching marine biology for half a century, and shares his experience of bringing the subject alive. Students are inspired by passion and there is plentyhere, both for the subject and of the more earthy kind. Kaplan discusses with aplomb the pheromones oflampreys, the reckless mating of one-eyed shrimp, and the broken-off reproductive organs of male squid. One might conclude that he is rather preoccupied with matters reproductive, but that is true of most biologists.

There are horrors lurking here too, such as the candiru - a fish that can wriggle up the urethra of its unfortunate victim to lodge in the bladder and feast on the blood. Other perils mentioned in the book include the poisons of the pufferfish, the cone shell and the innocuous-looking fruit of the manchineel tree - known with good reason as the 'death apple'.

This compendium of sex and death provides plenty for raconteurs wanting to leave a lasting impression on friends, relatives or - in Kaplan's case - students.

Each of the 31 chapters opens with either one of Kaplan's own memoirs or a scenario from his imagination, before exploring the marine biology behind the tale. As a result, a reader may sometimes wonder where the book is going, although the entertainment seldom flags. But

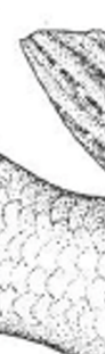

and learn invertebrate anatomy by preparing a paella. This is not educational sadism, as students are powerfully motivated by exposing all their senses to Steinbeck's “teeming boisterous life. Watching my own students scramble across rocky shores and peer tremulously under seaweed, I can only agree that these activities ignite interest and trigger understanding.

People sometimes ask me whether the world really needs more marine-biology graduates. Despite the vast challenge of exploring and understanding the marine realm, very few students actually become career scientists, as openings are highly competitive now that universities are turning out more and more $\mathrm{PhDs}$. Instead, most marine-biology students become professionals in other areas, from secondary-school teachers to accountants and entrepreneurs. I reassure prospective students that marine biology rewards its devotees with analytical and interpersonal skills that are

highly prized in a multitude of careers. It also instils culturally valuable understanding and respect for the natural world - and why not have some fun along the way? Kaplan's book conveys the breadth and excitement of an education in marine

this is in

keeping with Steinbeck's description of a true biologist: "Sometimes he may proliferate a little too much in all directions... meanwhile he is very good company, and at least he does not confuse a low hormone productivity with moral ethics."

Kaplan believes in hands-on teaching and advocates the necessity of literally immersing marine-biology students in their subject. Drawing on several decades of teaching field courses in the Caribbean, he describes making his students wallow in mud, chase specimens

\section{MORE ON THE SEA}

Underwater to Get Out of the Rain: A Love Affair with the Sea

by Trevor Norton (Arrow, £6.99)

\section{Astronomy through the years}

\section{The Cosmic Century: A History of \\ Astrophysics and Cosmology \\ by Malcolm Longair \\ Cambridge University Press:2006. 565 pp. $£ 35, \$ 60$}

\section{Jay M. Pasachoff}

John F. Kennedy once addressed what he called the "most extraordinary collection of talent, of human knowledge, that has ever been gathered at the White House, with the possible exception of when Thomas Jefferson dined alone". After diving into Malcolm Longair's epochal The Cosmic Century, a history of astronomy and astrophysics, he is the one I would want to dine with if I wanted to learn about an unlimited range of material.

Longair's book is a complete reworking and major extension of a chapter he once wrote for a history book of twentieth-century physics. This background perhaps explains how such a knowledgeable astronomer was inveigled into spending the time needed to gain such a broad view. It's no surprise that the author of Alice and the Space Telescope (Johns Hopkins University Press, 1989) can write clearly and invitingly, but I had to sample deeply to verify that he did not give short shrift to such wide-ranging topics as the discovery of exoplanets, the use of helioseismology to analyse the inside of the Sun, and 